\title{
Water-driven Palestinian agricultural frontiers: the global ramifications of transforming local irrigation
}

\author{
Julie Trottier ${ }^{1}$ \\ Jeanne Perrier \\ CNRS, France \\ Université Paul Valéry, France
}

\begin{abstract}
In agricultural transformations, small scale farmer driven processes interact with globally driven processes. Donor-led or foreign investor-led irrigation development systematically interacts with local, farmer-led irrigation development. This article harnesses Kopytoff's concept of 'interstitial frontier' to study such interactions. It discusses the shape an agricultural frontier may have and its interactions with local forms of water and land tenure. It discusses the manner in which changing access to water may spur the development of agricultural pioneer fronts. It distinguishes surface water driven, groundwater driven and wastewater driven agricultural frontiers. It then explores the manner such frontiers are transforming water tenure in the West Bank. This is an important aspect of the globalization of Palestinian society. The method this article develops is applicable elsewhere. Within interstitial frontiers, investors, whether local farmers or outsiders, enroll a globally maintained scientific discourse of efficient water use to secure donor funding. Meanwhile, they try developing clientelist ties with the authorities to secure their new access to water. The impacts on neighbouring, peasant-run irrigated systems, food security, housing security and many other mechanisms that sustain a society, are important and too often neglected.
\end{abstract}

Keywords: water, irrigation, agricultural frontier, West Bank, Palestinian agriculture, land tenure, water tenure, globalization.

\section{Résumé}

Lors d'une transformation agricole, des processus impulsés par les petits agriculteurs interagissent avec des processus impulsés à l'échelle globale. Le développement de l'irrigation mené par un bailleur ou par un investisseur étranger interagit systématiquement avec le développement de l'irrigation mené par les agriculteurs locaux. Cet article utilise le concept de front pionnier interstitiel, développé par Kopytoff, afin d'étudier ce type d'interactions. Il discute de la forme que peut prendre un front pionnier agricole et de ses interactions avec les formes locales de tenure de l'eau et de tenure foncière. Il explore la façon dont la transformation de l'accès à l'eau peut mener au développement de fronts pionniers agricoles. Il distingue les fronts pionniers impulsés par l'eau de surface, de ceux impulsés par l'eau souterraine et de ceux impulsés par l'eau usée traitée. Il se penche sur la façon dont ces fronts pionniers transforment aujourd'hui la tenure de l'eau en Cisjordanie. Ceci constitue un aspect important de la globalisation de la société palestinienne. La méthode développée ici peut s'appliquer ailleurs. Au sein de fronts pionniers interstitiels, les investisseurs, qu'il s'agisse d'agriculteurs locaux ou d'étrangers, déploient un discours scientifique, construit et entretenu à l'échelle globale, concernant l'efficacité de la gestion et de l'utilisation de l'eau, afin d'obtenir le soutien des bailleurs. Ils tentent simultanément de développer des liens clientélistes avec les autorités pour sécuriser leur nouvel

\footnotetext{
${ }^{1}$ Dr. Julie Trottier, Directrice de Recherche CNRS, ART-Dev, UMR 5281, Site St-Charles, Montpellier, France. Email: julie.trottier "at" cnrs.fr. Jeanne Perrier, PhD candidate, ART-Dev, Site Saint-Charles, Université Paul Valéry, Route de Mende, 34199 Montpellier, France. Email: jeanne.perrier "at" sciencespo.fr. The authors wish to thank referees, and the Agence Nationale de Recherche (ANR) for funding the project Of lands and water (ANR-12-AGRO-0002-01) as well as the Agence Française de Développement (AFD) for funding the project Governing the paracommons of Palestinian water (Contract $\mathrm{N}^{\circ}$ 153237). The results presented in this article emerge from research carried out in these two projects.
} 
accès à l'eau. L'impact sur les systèmes d'irrigation paysans voisins, sur la sécurité alimentaire, la sécurité d'habitat et bien d'autres mécanismes fondamentaux au sein d'une société, est immense et trop souvent négligé.

Mots clés: l'eau, l'irrigation, front pionnier agricole, Cisjordanie, agriculture palestinienne, tenure foncière, tenure de l'eau, globalisation.

\section{Resumen}

En las transformaciones agrícolas, los procesos a pequeña escala orientados a agricultores, interactúan con los procesos a escala global. El desarrollo de irrigación por parte de donantes o inversionistas foràneos, interactúa sistemáticamente con el desarrollo local de irrigación de los agricultores. Este artículo emplea el concepto de "frontera intersticial" de Kopytoff para estudiar dichas interacciones. Se discute la forma que puede tener una frontera agrícola, así como sus interacciones con formas locales de la tenencia del agua y de la tierra. También se aborda la manera en que el cambiante acceso al agua puede estimular el desarrollo de nuevos frentes agrícolas. Se hace una distinción entre fronteras agrícolas determinadas por superficies de agua, por agua subterránea y por aguas residuales. Posteriormente se explora la manera en que tales fronteras están transformando la tenencia del agua en la Ribera Occidental. Todo esto es un importante aspecto de la globalización de la sociedad palestina. El método que desarrolla este artículo puede aplicarse en cualquier otro sitio. Dentro de las fronteras intersticiales, los inversionistas, sean agricultores locales o foràneos, se inscriben en un discurso científico de uso eficiente del agua para así asegurar financiamiento de donantes. Mientras tanto, ellos procuran desarrollar vínculos clientelares con las autoridades para asegurar un nuevo acceso al agua. Los impactos por la colindancia, sistemas de irrigación manejados por campesinos, seguridad alimentaria, seguridad de vivienda y muchos otros mecanismos que sostienen una sociedad son importantes y frecuentemente desatendidos.

Palabras clave: agua, irrigación, frontera agrícola, Ribera Occidental, agricultura palestina, tenencia de la tierra, tenencia del agua, globalización

\section{Introduction}

How does the present transformation of Palestinian irrigation interact with the ongoing globalization of Palestinian society? Irrigation involves an interaction both with water tenure and with land tenure. The term tenure designates the relations among human beings that construct the regulation of their interactions with a natural resource such as water or land (Hodgson 2016). In the West Bank, both types of tenure are presently undergoing simultaneous but contradictory transformations driven by actors who deploy their strategies over a great variety of scales. These range from the very local, such as a small plot of land, to a global scale. Answering such a question requires us to understand how small farmers, international donors, foreign investors, and national actors such as Israel and the Palestinian Authority construct and transform water and land tenure.

This article argues that interactions between donors and the Palestinian Authority (PA) are presently driving the development of wastewater pioneer fronts within interstitial frontiers in the West Bank, while Palestinian farmers are driving the development of groundwater pioneer fronts within other interstitial frontiers. Both types of pioneer fronts are having a major impact on societal interactions concerning the environment. They contribute to the dispossession of ancient water users and to the destruction of long established water tenure systems. They are transforming Palestinian society. Wastewater pioneer fronts, especially, are transforming water into a commodity. The present mantra on wastewater reuse in agriculture, among donors and international organizations, portrays this as an efficiency improvement.

This article provides empirical material on crucial changes in the social and political processes driving Palestinian agriculture. It also develops a method to study the interactions between globally driven processes and small-scale farmer driven processes concerning water appropriation within agricultural development. Such tenure issues are not unique to the Palestinian situation. Such a method is applicable elsewhere in the world. 
In the case of the West Bank, upon hearing 'frontiers', most readers will think of Israeli occupation and the ensuing expansion of settlements in the occupied territories. Frontier expansion through agriculture is usually associated with large territories such as Brazil or Mozambique. However, following Kopytoff, who demonstrated the crucial role played by interstitial frontiers in ethnogenesis in Africa, this article explores the small-scale agricultural pioneer fronts being developed in the West Bank by Palestinian actors. The West Bank is a small space: 5,655 km² (OCHA 2015). It is densely populated, with 585 person/ $\mathrm{km}^{2}$ in 2015 if we include 556,000 Israeli settlers and 2.75 million Palestinians (OCHA 2015). It is scarcely associated with the development of agricultural frontiers. Yet, fieldwork reveals their existence within either uncultivated areas or areas used non-intensively, nestled among villages, towns, Israeli settlements and intensively cultivated areas.

Section 2 first sketches an overview of the various literatures that can contribute to the theoretical framework necessary to study the transformation of irrigation in a multi-scalar manner. Section 3 then examines the nature of pioneer fronts and how they need to be conceptualized. The critical point for this article is that new land control creates new frontiers. A pioneer front is usually defined as a space where agriculture is being extended over previously uncultivated land. We re-examine this definition using cases around the world, especially Africa, and argue that a more precise definition of pioneer fronts should refer to the transformation of our interactions with the environment that are linked to the transformation of power relations within society. A pioneer front involves an in-depth reconfiguration of farmers' interaction with land and water that goes beyond turning to high yield varieties or an increased use of fertilizers. Within a pioneer front, land tenure and water tenure are deeply modified. The modalities of access to both land and water are transformed. Appropriation modalities are transformed.

Section 4 then explores case studies of groundwater pioneer fronts and wastewater pioneer fronts presently occurring in the West Bank. None of the farmers developing them aimed to intensify production because of a food shortage. All of them aimed to sell their crops either on the local market or through exportation. Finally, section 5 discusses the global ramifications of these developments in terms of power structures governing relations among social groups in the West Bank. These pioneer fronts are transforming Palestinian interactions with the environment. They clash with pre-existing forms of water tenure, i.e. peasant run, irrigated agriculture. They impact both the environment and the manner political structures interact with it. Such pioneer fronts are interstitial, local frontiers acting as a crucible where Palestinian investors enrol the scientific discourse on efficient water use to secure donor funding while developing clientelist ties with the PA to secure their new access to water.

These interstitial frontiers are spaces of true globalization as the newcomers to agriculture deploy a globally maintained discourse on water, rely on foreign aid and often aim to develop export-oriented agriculture. Globalization appears here in the manner Palestinian actors are harnessing a scientific discourse constructed at the global scale, in great part by globalized companies adhering to a neoliberal agenda. Here, local actors deploying this globally constructed discourse with the support of international donors are transforming the power relations, within their society, that govern human interactions with the environment. The neighboring Palestinian, peasant run irrigated agricultural systems are their first casualties.

This study in no way denies the fact that the West Bank is still under military occupation. It does not deny the fact that Israel still pursues settlement activities, including agricultural settlements. It does not deny the fact that Israel still abstracts water from wells located in the West Bank and develops Israeli-led agricultural pioneer fronts. Our focus, however, is to explore how Palestinian led agricultural pioneer fronts are presently transforming societal interactions concerning the environment, especially concerning water. Such intra-Palestinian political mechanisms are important. The role donors play here is quite large. The reality of Israeli occupation should not deter researchers from studying such Palestinian political developments.

\section{A multiplicity of epistemic communities tackling land and water}

Ever since Bassett (1988: 454) described the political ecology model as combining (1) progressive contextualisation, (2) a historical approach to the transformation of indigenous systems, (3) an emphasis on state intervention on land use patterns, (4) a focus at the local level on the responses of actors to changing social relations of production and (5) a sensitivity to regional variability, several strands of literature emerged 
that touched upon issues of land and water tenure. When studying the Khorezm oasis, south of the Aral Sea, Baker Brite noted that "people's attitudes, behaviors and actions towards the environment were not the same in any given period" (Baker Brite 2016: 4). This means irrigation systems and their consequences take different forms at different periods of time. The same holds true for actors who irrigate at the same periods of time, within the same space, but are embedded in completely different human interactions governing their management of land and water. The present Palestinian transformation of irrigation illustrates this. Several theoretical approaches have spurred the development of independent epistemic communities, each supplying us with theoretical advances that contributed to studying the present Palestinian pioneer fronts.

Considering the political ecology of irrigation requires paying specific attention to the construction of the scientific discourse concerning the efficiency of water use in agricultural transformation, as much as it does paying attention to the construction of the political discourse concerning the legitimate appropriation of land and water. The construction of scientific discourses on the environment is always intertwined with the political processes concerning this environment (Forsyth 2003; Goldman, Nadasdy et al. 2011). Answering our question thus first requires us to examine rigorously the manner in which scholarship has depicted agricultural transformations and irrigation.

Scholarship on globalized agricultural transformations since 2008 has overwhelmingly focused on interactions between foreign investors, host states and local 'elite' investors seeking to secure land. It has mostly explored processes that crossed borders and led to a 'foreignization' of space and land (Zoomers 2010). It has paid less attention to processes driven by small-scale farmers. This scholarship soon recognized that the focus on the 'buyers' in land deals risked overlooking the dynamics that operate on the side of the land 'sellers' (Woodhouse 2012). It noted the need to pay attention to the manner in which the 'transmission belt of prices' meant that foreign investments affect local farmers' access to land and other resources even when they are not targeted by these investments (De Schutter 2011). It also noted the need for more comprehensive and systematic empirical research on resistance (White et al. 2012).

This scholarship recognized the need for more rigorous empirical work and questioned the manner in which studies framed dichotomies that reflected the ideological biases of the researchers (Oya 2013). While it questioned the epistemology underlying the datasets, it also acknowledged the lack of focus on social relations transformed by processes of agricultural transformation. Most of the literature on land grabbing used 'hectare-centric analysis', producing numerous quantitative studies with many uncertainties about the data collected (Edelman 2013). Some preferred using the term "land control" to refer to "'practices that fix or consolidate forms of access, claiming, and exclusion for some time" (Peluso and Lund 2011: 668). New land control creates new frontiers. These are sites where new territorialization processes challenge power and social relations. Such processes are presently occurring in Palestinian Territories. The overwhelming focus on the Israeli-Palestinian conflict has led researchers to neglect them up to now. This has led to many studies on land grabs by Israeli settlements but has meant that the new frontiers within Palestinian society and Palestinian territory have rarely been explored.

Agriculture relies on water as much as it does on land. The land grab literature noted early the fact that international investors seeking large land acquisitions would also need to secure large quantities of water. It initially tackled the link between water and large land acquisitions only in terms of international law (Smaller and Mann 2009). Later attempts at exploring this link within African agricultural transformations maintained this international focus (Allan et al. 2013). Few tried to explore or theorize how small-scale farmer-driven processes interact with globally driven processes. Yet, a crucial part of the transformation of water access, use and control lies within the global transformation of agriculture. A 'water grab' literature emerged in the wake of the land grab literature. It deployed the theoretical framework predominating in the land grab literature to examine the dispossession of local communities by powerful actors (Mehta et al. 2012). It defined water grabs on the basis of three criteria used to define land grabs: (1) 'control grabbing' as defined in the theory of access (Ribot and Peluso 2003), (2) the scale of the appropriation either in terms of surface area or capital, and (3) their occurrence within the dynamics of capital accumulation strategies that are largely responses to crises. It identified a difference between land grabbing and water grabbing given the fluid nature of water, which makes it more complex. It recognized that powerful actors may be of the same nationality as the communities they dispossess. It focused, however, on dispossession by powerful actors. Thus, it sheds light 
only on a subset of transformations of land and water tenure within the agricultural transformations that pioneer fronts represent.

The land grab literature led others to coin the term green grabbing. It describes the appropriation of land and resources for environmental ends (Fairhead, Leach and Scoones 2012). It doesn't necessarily entail the alienation of land from its claimants. Rather, it involves "the restructuring of rules and authority over the access, use and management of resources, in related labor relations, and in human-ecological relationships, that may have profoundly alienating effects." (Fairhead, Leach and Scoones 2012: 239).

Small-scale farmers are rarely construed as actors driving irrigation development. Yet, they invest significantly in water management to intensify agriculture. Their developments remain invisible to formal planning institutions, government agencies and international organizations for several reasons (Woodhouse 2012). The social models deployed in discussions of agricultural development, whether it be in Africa or in the Middle East, don't engage with existing dynamics of social and agrarian change. The dichotomies they deploy, such as the distinction between irrigated and rain-fed agriculture, also contribute to this invisibility. Small-scale farmers often develop irrigation that is complementary to and integrated into rain-fed farming. As their irrigation management remains informal, it doesn't feature in national statistics. The innovations they develop, such as in mountainous terrain, are not perceived as 'irrigation' by mainstream observers. Policies in Sub Saharan Africa frame 'irrigation development' as a transfer of technology from abroad and portray smallscale farmers as beneficiaries instead of agents of irrigation development (Woodhouse et al. 2016). Policies in the West Bank do the same thing (Trottier and Perrier 2017).

Woodhouse et al. defined 'farmer-led irrigation development' as a process whereby farmers drive the improvement of their water use in changing knowledge production, technology use, investment patterns, market linkages and the governance of land and water (Woodhouse et al. 2016). Although their focus was on Africa, the same farmer-led irrigation development was observed in Palestinian Territories (Trottier 1999, 2015). When international investors or donors target agricultural development, they never do so in a vacuum. Their efforts to transform water use necessarily interact with the processes driven by small-scale farmers to develop irrigation according to their own constraints and needs. This article proposes an approach to study such interactions between globally driven mechanisms and locally driven ones.

We propose harnessing Kopytoff's concept of 'intersitial frontier' to study the development of agricultural pioneer fronts. Kopytoff coined the term 'interstitial' or 'local' frontiers to designate open areas nestling between organized societies but 'internal' to the larger regions in which they lay. 'Frontiers' usually evoke a sweeping tidal wave across a continent or a large landmass, where settlers colonize a land, arriving from a metropolitan society "whose authority follows on their heels" (Kopytoff 1987: 8). While such a model fits the description of American history, this 'tidal frontier' doesn't match pre-colonial African history. Yet, African societies showed many centrifugal forces generating population mobility. People fleeing family feuds or witchcraft trials, or people expelled from their extended families, for example, would systematically move to a marginal territory. This 'interstitial frontier' became the crucible of new social ties. Incoming migrants constructed a new society on the basis of the categories they imported from their former homes. This process explains the plurality of forms of political organization in Africa as well as the incessant reproduction of ethnic diversity. An interstitial frontier is necessarily a transient phenomenon. Either the new ethnicity becomes dominant and expands or it disappears.

Initially developed by Kopytoff to explain ethnogenesis in Africa, the concept of 'interstitial frontier' was later harnessed to study migrations in Africa (Chauveau, Jacob and Le Meur 2004). It also proved useful to explore the interactions between processes driven by indigenous populations and state-driven processes during the Mexican land reform between 1934-1941 (Léonard 2004). The concept is not tied to an African idiosyncrasy.

\section{What is a pioneer front?}

Most simply defined, a pioneer front is a space where agriculture is being extended over previously uncultivated land. Such a definition ignores the fact this land was unavoidably already used. It could have been home to an ecosystem devoid of human interference, hence the site of non-human uses. It could also 
have been the site of hunting grounds, of a non-intensive, perhaps intermittent, grazing area or of small-scale subsistence farming. For example, in Maranhao and Piauf states in Brazil, small-scale ranching or subsistence production prevailed before the development of an agricultural frontier (Jepson 2006). Hence a more accurate definition of a pioneer front is a space where farming practices are suddenly intensified over land that had previously been used far less intensively.

Scientific studies often depict pioneer fronts as beneficial developments. In such cases, they usually represent them using mathematical equations and graphs putting forward measurements such as surface area, volumes of water, or crop yields. Examples include the representation of the progress of global biofuel production (Hertel, Steinbuks, and Baldos 2013), the projected water consumption in agriculture (Pfister et al. 2011) or the representation of the link between land surface, crop yield and profitability (Chamberlin, Jayne, and Headey 2014). Such literature depicts the intensification of agriculture or food production as beneficial to mitigate climate change, through the production of biofuels, or to ensure food security. It insists on the productive aim of this process.

Many studies of agricultural intensification, however, highlight its negative environmental impact. They draw world maps of soil degradation and resulting productivity (Gomiero 2016). They map watershed degradation through soil loss resulting from agricultural expansion such as in areas of Nepal (Krishna Bahadur 2012). They demonstrate the erosion and disappearance of natural vegetation in the Cerrado, Brazil, caused by pioneer fronts (Grecchi et al. 2014). Such studies demonstrate that pioneer agricultural fronts impact many more resources than land alone. The extension of agriculture systematically extends over other resources, whether they be water, or biodiversity.

State policies sometimes reallocate land in order to extend or intensify agriculture. However, this may reduce the overall cultivated area. In Zambia, the number of "emergent farmer households", i.e. farmers cultivating 5 to 20 hectares of land, grew by 62.2 percent between 2001 and 2011 (Sitko and Jayne 2014: 195). Local urban elites acquired customary land converted to leaseholds thanks to government policy officially aimed at smallholders. Showing little interest in agriculture, they cultivate a significantly smaller proportion of their land than smallholders do (Sitko and Jayne 2014: 201). Much of the literature thus describes pioneer fronts as land grabs carried out either by local elites or foreign investors.

Ground truthing based on fieldwork demonstrates the inaccuracy of global models when depicting pioneer fronts at the local level. For example, models describing agricultural transformation in the north of Mozambique on the basis of yield gaps, profitability and surface areas, are based on assumptions that don't resist scrutiny. Such models rely, for instance, on the erroneous assumption of monocropping on land where farmers systematically associate several crops (Leblond 2017). Clearly, pioneer fronts do not necessarily entail a veritable intensification of agriculture. Rather, they entail a transformation of our interaction with the environment. This transformation is represented more or less accurately by some of the actors involved, through various means such as models, as the intensification of agriculture.

A more precise definition of pioneer fronts should refer to the transformation of our interactions with the environment that are linked to the transformation of power relations within society. Pioneer fronts systematically entail the transformation of relations among many actors concerning land, capital, labor and water. Jepson demonstrated the roles played by a variety of actors, such as firms and agricultural cooperatives, in Brazilian pioneer fronts, showing how rural organizations served as intermediaries, negotiating with state bureaucracies on behalf of farmers (Jepson 2006). Cochet, Léonard, and Tallet demonstrated the 'reverse tenancy' that developed in twentieth century Mexico. Here, the agrarian reform distributed small land grants to poor peasants. Unable to purchase cattle to graze on their land, they entered sharecropping agreements with rich cattle owners powerful enough to dictate terms to their advantage. This pioneer front spurred the rise of landless latifundia, where large cattle owners preferred using the land of small peasants rather than their own land for pasture (Cochet, Léonard, and Tallet 2010).

\section{Water and pioneer fronts}

The extension of agriculture over previously uncultivated land, or its intensification, is often driven by a newly accessed supply of water. We can thus distinguish three types of water supply-driven pioneer fronts: 
surface, groundwater and wastewater pioneer fronts. The first two may be led either by farmers, by a network of farmers and state officials or by a network of farmers, state officials and donors. Wastewater fronts, however, are only state-led or led by a network of state, donors and investors.

Within government run, surface water irrigation schemes with canals, farmers who purchase pumps can access more than their official allocation, providing state authorities turn a blind eye. Downstream farmers relying on the same infrastructure then suffer as they no longer receive their expected share. This is happening in the Fayoum, Egypt, for example (Barnes 2012). Further north, in the West Delta, capital intensive farmers pumped groundwater to the point that its level dropped significantly. These investors succeeded in convincing the Egyptian state to deviate Nile water from the existing canals to their land, lying outside the Delta, in the desert, in order 'to leave water in the aquifer.' The state takes water out of the Rayah al-Nasseri Canal, thus depriving downstream users. Egypt harnessed donor funds for such a project. It argues that increasing the efficiency of water use in the old lands, where traditional surface irrigation can be replaced by sprinkler or drip irrigation, can free up enough water to reclaim 2.6 million acres (1,052,183 ha) outside the delta (Barnes 2012). They model such impacts using climatic and agronomic variables alone. Studies rarely pay attention, as Barnes did, to the way in which surface water driven pioneer fronts entail transformations in the relations between social groups. In the Fayoum, individual farmers acquiring pumps dispossess downstream users with the passive support of the state. In the West Delta, a network of rich bankers, foreign donors and the state actively dispossess traditional users. Portraying them as 'inefficient water users' legitimizes this dispossession.

Similarly, groundwater driven pioneer fronts rely on pumping capacity and can be either farmer or state-driven. The complex shape that aquifers may take can lead to a variety of scenarios. In the Saada basin, Yemen, farmers started drilling wells in 1972 when a Muslim scholar provided a new interpretation of Muslim law, allowing such previously forbidden drilling (Lichtenthaler 2003). The resulting mining of the aquifer led to a rapid drop in groundwater level. Farmers had to 'run after the water', deepening their wells and equipping them with more powerful pumps. Land concentration ensued as a growing number of farmers gave up, unable to find enough capital to continue. The obvious damage to the ecosystem worried the population enough that they welcomed a new interpretation of Muslim law, based on the concept of common good, that ended aquifer mining by the 1990s (Lichtenthaler 2003). In this case, a farmer-driven, groundwater pioneer front, which started on an unsustainable course, found institutional resources locally to modify its practices and become more sustainable.

Specific associations between the state and commercially oriented farmers often drive groundwater pioneer fronts. In the Middle East, large plains remained vulnerable to Bedouin incursions until the middle of the nineteenth century. Thus, irrigated agriculture tended to develop in the mountains that were less accessible (de Planhol 1968). Consequently, European colonizers found large uncultivated plains from Morocco to Lebanon. French authorities started mining the aquifer of the Souss plain, Morocco, in the 1930s. By 1975, groundwater level had dropped 20 to 30 meters (Boujnikh and Humbert 2010). The Moroccan state started to bring surface water from the western Atlas to lessen the pressure on groundwater while leading an agrarian reform distributing land in the Souss to small peasants. They pursued further mining of the aquifer through the cooperative organizations that the state set up to allow them to irrigate. By the late 1990s, this pioneer front reached the edges of land that was traditionally irrigated in higher altitude villages.

Traditional peasant irrigation relied on khettaras, underground tunnels dug horizontally in the mountain. Their existence and maintenance rely on considerable social capital within the communities that use and maintain them via common property regimes. Khettaras are drainage systems linked to an aquifer. A ten meter drop in water level can isolate the gallery from the aquifer and dry it out totally. The only solution then consists in digging a new khettara under the older one. Higher land then becomes un-irrigable, which reduces the cultivable area in the village. By 2008, most of the khettaras around the Souss plain had dried up (Boujnikh and Humbert 2010). Thus the progress of a state-assisted, capitalist and export-oriented pioneer front based on the unsustainable mining of the Souss plain drove the disappearance of village-run, khettara based, gravity fed irrigation. Such systems have proved their sustainability since the fifteenth century through the elaboration of complex common property regimes governing both land and water tenure. 
Wastewater driven pioneer fronts are the most recent. The scientific literature promotes them without considering the manner in which they may affect farmers already irrigating using surface- or groundwater. Treated wastewater that is not reused is systematically presented as being 'wasted.' Examples of such approaches are illustrated by Abu-Madi et al. (2009) and Miller (2006). Models estimate the volumes of wastewater produced by cities and the volumes that are reused in agriculture to calculate a 'wastewater gap' that should be harnessed (Alfarra et al. 2011). Social science literature focuses on what it perceives as three obstacles to wastewater reuse: acceptance, institutional obstacles and economic and financial impediments to change (Beveridge, Moss, and Naumann 2017). Even when noting that wastewater reuse shapes territorialisation, defined as the processes of bordering, bounding and enclosure, these authors view it positively as advancing sustainable land and water management.

Yet, releasing treated wastewater in the environment cannot be construed as 'wasting' it. Once in the environment, it recharges the aquifer which supplies the springs and the wells used by a great variety of irrigating farmers. Releasing treated wastewater into the environment usually means relinquishing direct state control over its next use. But the environment and farmers using wells and springs governed by common property regimes use such water. It is not wasted.

Wastewater driven pioneer fronts rely on large infrastructure usually built by a state. Hence, these pioneer fronts are state driven and, where states rely on foreign aid, they are state- and donor-driven. In the same way as surface water and groundwater pioneer fronts compete and clash with previous forms of irrigation, wastewater pioneer fronts entail a transformation of power relations that govern human interactions with their environment.

\section{What pioneer fronts do we observe in the West Bank?}

No surface water-driven pioneer front presently exists in the West Bank because the extension of agriculture, thanks to surface water, has already been carried out wherever Palestinians can access it. However, numerous interstitial groundwater and wastewater driven pioneer fronts are developing.

Low population density prevailed until the late nineteenth century in what is now Israel and the West Bank. To villagers, human labor and, in places, animal traction were the limiting factors in agriculture, not land. On the plains, villages usually gave a plot of land, often a house, and sometimes even draught animals to any new incoming family. Up to the second half of the nineteenth century, villages located on the plains sought to maximize the number of men available to fight potential Bedouin incursions (Granott 1952: 73). The use of springs in agriculture was developed progressively, as the areas under cultivation increased, accelerating in the last decade of the nineteenth century (Trottier 2013). Palestinians accessed surface water from springs and from the Jordan River without state intervention, devising local regulations to manage their interactions. Jordan did not interfere with this during the period it ruled the West Bank from 1949 to 1967 (Trottier 1999). Israeli occupation starting in 1967 reduced Palestinian farmers' access to surface water. First, it ended Palestinian irrigation from the Jordan river (Trottier 2013). The progressive appearance of Israeli settlements and national parks in the West Bank later curtailed Palestinian access to many springs. This process continues to this day.

The overwhelming majority of remaining springs accessible to Palestinians in the West Bank have been used for many centuries, as in Battir. These are managed thanks to farmer-run common property regimes. Neither Israel nor Jordan ever interfered with the inner functioning of these informal institutions. Yet, their mode of tenure, typical of common property regimes, was not recognized by the 2002 Palestinian water law and the later 2014 decree. Its article 3 stipulates that 'All water resources in Palestine shall be considered public property, and the Authority has the power to manage these resources in a manner that ensures justice and efficiency in distribution.' Its article 31 mentions 'In accordance with the provisions of this law taking into considering (sic) the designation of water as a public property, the Authority shall prepare the following regulations and submits (sic) them to the Cabinet of Ministers for issuance: A) Fees per water quantity licensed for extraction from all wells or exploitation from springs, B) Prior use rights from springs or licensed quantity of water extracted from wells.' These prior use rights have not been listed or detailed to this day. 


\section{Groundwater-driven pioneer fronts}

Several types of interstitial groundwater pioneer fronts are present in the West Bank. All farmer-led, they fall within two main categories: those relying on pre-existing, licensed wells and those relying on new wells drilled without a license. They both transform the landscape, but they have a very different impact on the social construction governing water appropriations.

The first category of groundwater pioneer fronts, relying on pre-existing, licensed wells, can be found in the western aquifer, in the region surrounding Qalqilya and Tulkarem for example. Wells appeared in this area from the 1950s until 1967, when Israeli military order number 158 submitted well drilling to prior authorization through a permit. Farmers pooled their savings to fund drilling and created, for each well, a shirket al-bir, i.e. a 'well company' with written statutes. Often mistakenly described as private wells, they operate as common property regimes (Trottier 2015). The well operator notes the names of each farmer who receives an hour of water pumped from the well. The well accountant bills farmers monthly for the exact number of hours during which the well pumped water to their fields. Each plot of land is usually connected to one well only. The well accountancy is easily accessible to all, as transparency is crucial for the operation of a common property regime. And when a farmer is unable to pay, a situation that is easily verified via village life, a 'payment plan' is established. In other words, the farmer gets free water until his situation improves.

The organization of a shirket al-bir systematically privileges maintaining social ties and solidarity within the village. It doesn't aim at generating profit from selling water. The number of shareholders grew in every shirket al-bir since the 1950s, via the inheritance of the founders' shares distributed among their sons. This reinforced their functioning as a commons. Many such organizations count several dozen shareholders, meaning that many farmers relying on their well have family ties with people in the organization 'owning' the well.

Increasing urbanization now leads villagers to build houses on previously irrigated land. This reduces the amount of water required from the well linked to this land, leading many to pump far less than the quotas ascribed to them by the Israeli authorities since 1967. Simultaneously, the separation wall constructed by Israel since 2002 isolates much of these villages' land from the wells irrigating it and from the villages themselves, making it difficult for farmers to sustain cultivation. As a result farmers have started cultivating land much further from and higher than the villages, where, until recently, sheep roamed among rain-fed olive groves. Those who can afford it are making sizeable investments, cutting the mountain into terraces using heavy equipment. A farmer in the Tulkarem area, for example, spent 120,000 NIS ${ }^{2}$ in 2013 to construct terraces over one hectare of land he had purchased. In his village, six wells pump far less than their quota. He relies on a large reservoir recently built at an altitude even higher than his newly developed land. Water is pumped from one of the pre-existing licensed wells into this reservoir and then uses gravity to reach his land via a pipe system he set up himself. This farmer uses drip irrigation to produce greenhouse-grown strawberries for the local market. His reliance on a far-away well, located below his land forces him to pump water into a reservoir higher than his land. This entails great expense and water leaks. Yet, such reservoirs have been heavily funded by donors from 2011 onward within projects claiming to increase efficiency. Donors have thus taken part in this groundwater pioneer front led by local Palestinian farmers. Drilling a new well close to his land is forbidden, a rule that is enforced in this part of the Western aquifer. This farmer is structurally constrained into a use of water that is labelled 'inefficient' in spite of the heavy investments he has made.

In Habla, south of Qalqilya, another local farmer similarly developed expensive terraces in land located above the area traditionally irrigated thanks to the existing, licensed wells, many of which are also under-pumping their quota. He planted avocado trees which he manages to irrigate in the summer, relying on the closest available well. As all other farmers developing this interstitial pioneer front are now relying on the same well, it already pumps its full quota and operates 24 hours a day during the summer. As his small avocado trees grow, so will his demand for water. In 2015, this farmer irrigated in the middle of the night

\footnotetext{
${ }^{2}$ NIS stands for New Israeli Shekel. In 2013, this sum amounted roughly to US\$ 24,000.
} 
during the summer in order to have enough pressure in the system. He has no other source of water to turn to except, perhaps, setting up a long system of pipes to reach one of the far away wells that is presently underpumping its quota. He is also structurally constrained into a use of water considered 'inefficient.'

The second category of groundwater pioneer fronts, relying on the drilling of unlicensed wells, often occurs in the eastern aquifer and in the northern aquifer. In Wadi Al Far'a, for instance, 'Ein Miska spring and 'Ein al-Far'a spring started disappearing in 1995 and 2005 respectively, dried up by the unlicensed sinking of new wells in the surrounding area (Tomazi and Naslun 2005). Both springs were fully used for irrigation. Some 35 hectares depended on 'Ein Miska spring alone, via a communal property regime that apportioned shares in water within a regular rotation and maintained the $2.5 \mathrm{~km}$ long stone channel. The letters the spring users sent to the water authority in Nablus and to the Ministry of Agriculture to protest over these unlicensed wells proved useless. The powerful Nabulsi families who drilled the incriminated wells had a more privileged access to the ministries. Some of these wells were licensed a posteriori by the PA. The development of the unlicensed groundwater pioneer fronts in Wadi al-Far'a was a major loss for these peasant-run common property regimes. 'Ein Miska spring, for example discharged 1,317,000 cubic meters of water annually through a continuous flow between 1970 and 1994 (Tomazi and Naslun 2005). It is now completely dry, even in winter. By 2017, a farmer owning 1 hectare of land previously irrigated by 'Ein al-Far'a spring explained that he had cut down all of his orange trees while his cousin now bought water from the well owner who had dried up the spring he used to rely on.

Such unlicensed wells have no written statutes at the moment when they are drilled. As opposed to the licensed wells referred to earlier, they are private wells. Their owners achieve resource capture in an unregulated environment because they resort to a technology, wells and pumps, that didn't exist when the local water tenure had earlier been elaborated around springs. They benefit from clientelist relations they establish with the PA which turns a blind eye when they drill wells. One farmer in Jenin area drilled such an unlicensed well in 2012 next to a major road, for example. The well-drilling material was large and obvious, and the drilling lasted several weeks. PA officials could not fail to notice this drilling in broad daylight, but didn't intervene. Of course, Israeli wells also exist in the West Bank and have dried up springs such as the ones in Ein al-Beida, Kardala and Bardala (Trottier 2015). This article does not seek to deny this phenomenon. However, it focuses on Palestinian driven pioneer fronts.

Figures 1 and 2 show a Palestinian interstitial agricultural frontier located between the villages of Yasid, Beit Imrin and Jaba'. The picture was taken from the top of Mount Bayzid, facing east. It shows the new terraces corresponding to exploitation 1 on the map in the foreground, already covered with trees. In the middle it shows the new terraces that were being carved out of the mountain in 2017 and which had not appeared by the time the satellite picture used as a background raster in Figure 1 was produced. These terraces correspond to exploitation 2 on the map. The picture shows, furthest away, the terraces that correspond to exploitation 3 on the map, which had just been carved out when the satellite picture was produced. This pioneer front is located on the southern slope of the ridge and its construction started from the top of the ridge along which the irrigation pipe runs. The rest of the land is either fallow or covered with rain-fed olive trees. Sheep roam here to pasture, accompanied by their shepherds. The new terraces are mostly planted with irrigated guava trees and are fenced to prevent intrusion by sheep and people. The older, traditional terraces in the surrounding hills as seen on Figure 4, are built and maintained manually, so their walls are about one meter to two meters high. The terraces of the pioneer front, as seen in Figure 3, are far higher, and require heavy and costly machinery to build them. 


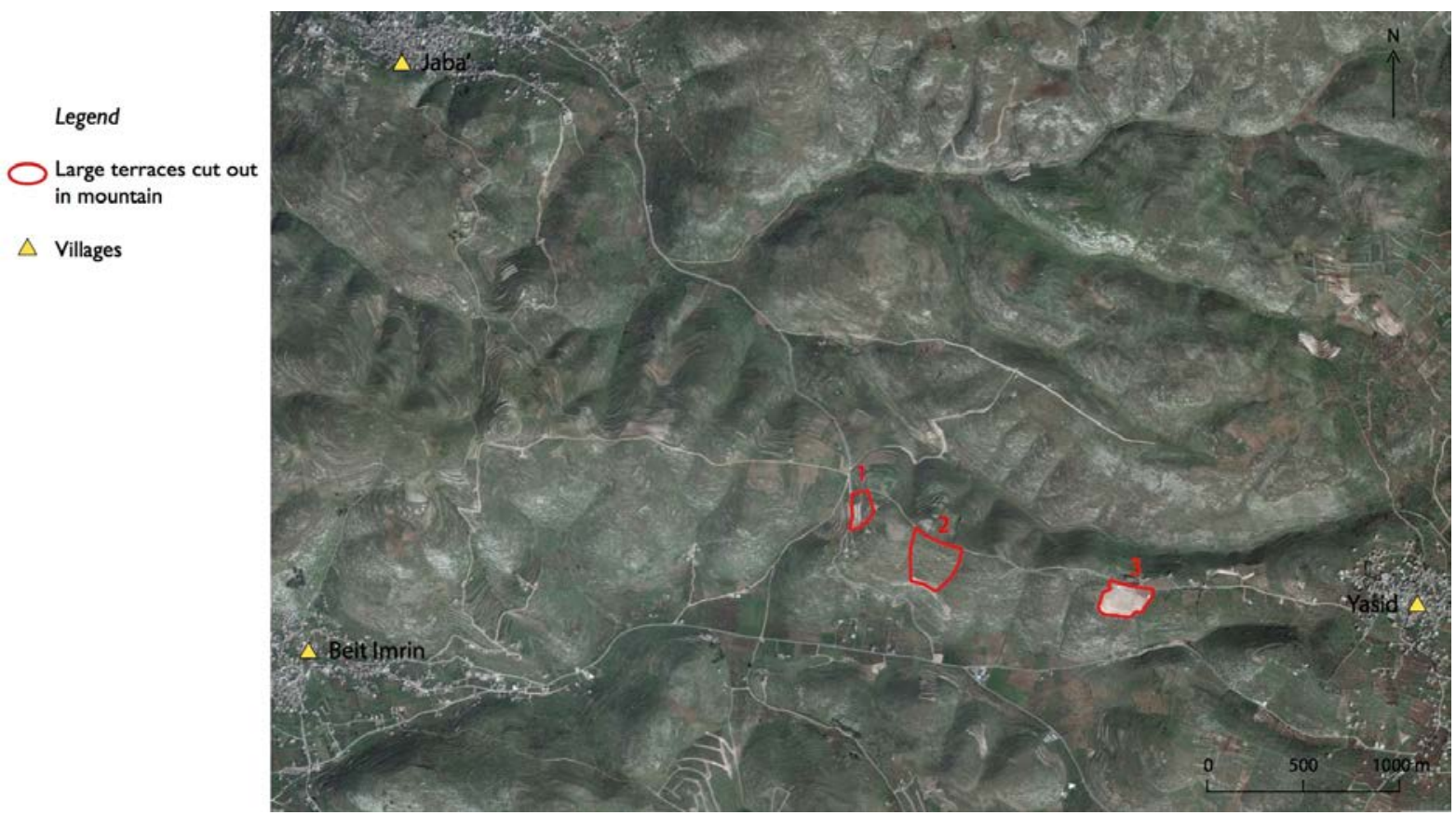

Figure 1: An interstitial pioneer front developed between Yasid, Beit Imrin and Jaba'. Source: authors.

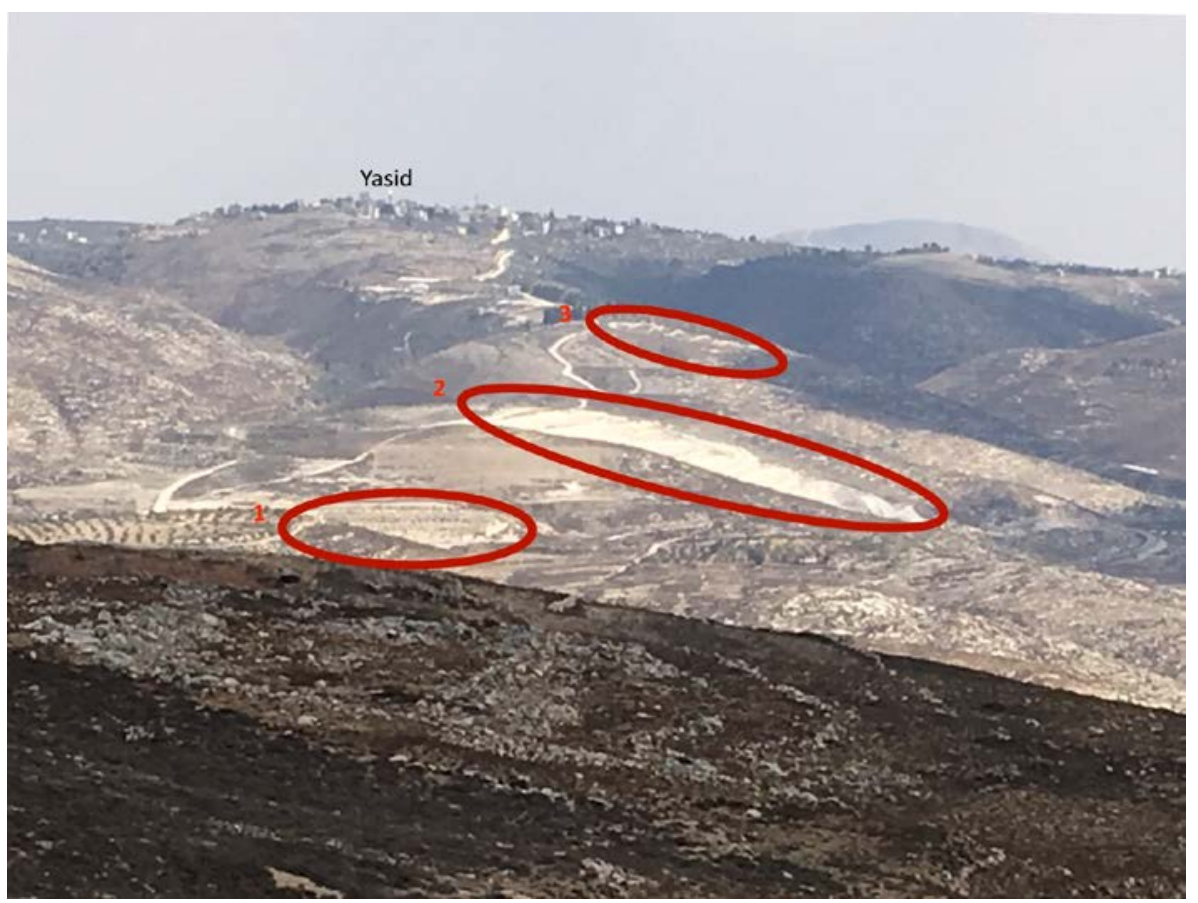

Figure 2: The interstitial pioneer fronts appearing in Figure 1. Source: authors. 


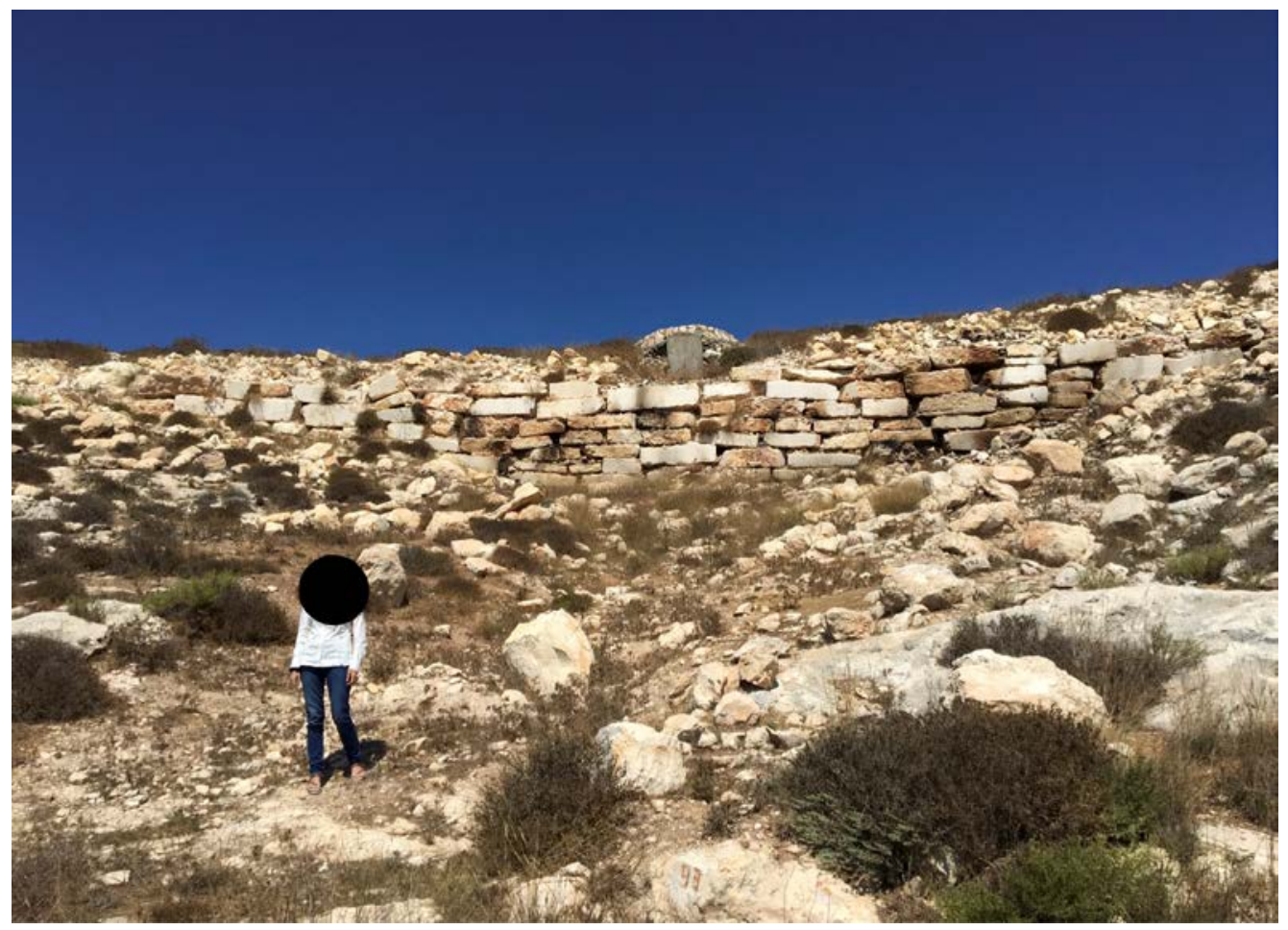

Figure 3: The southern wall bordering the terraces of a new agricultural pioneer front between Yasid and Beit Imrin. It corresponds to exploitation 2 represented in Figure 2. Source: authors.

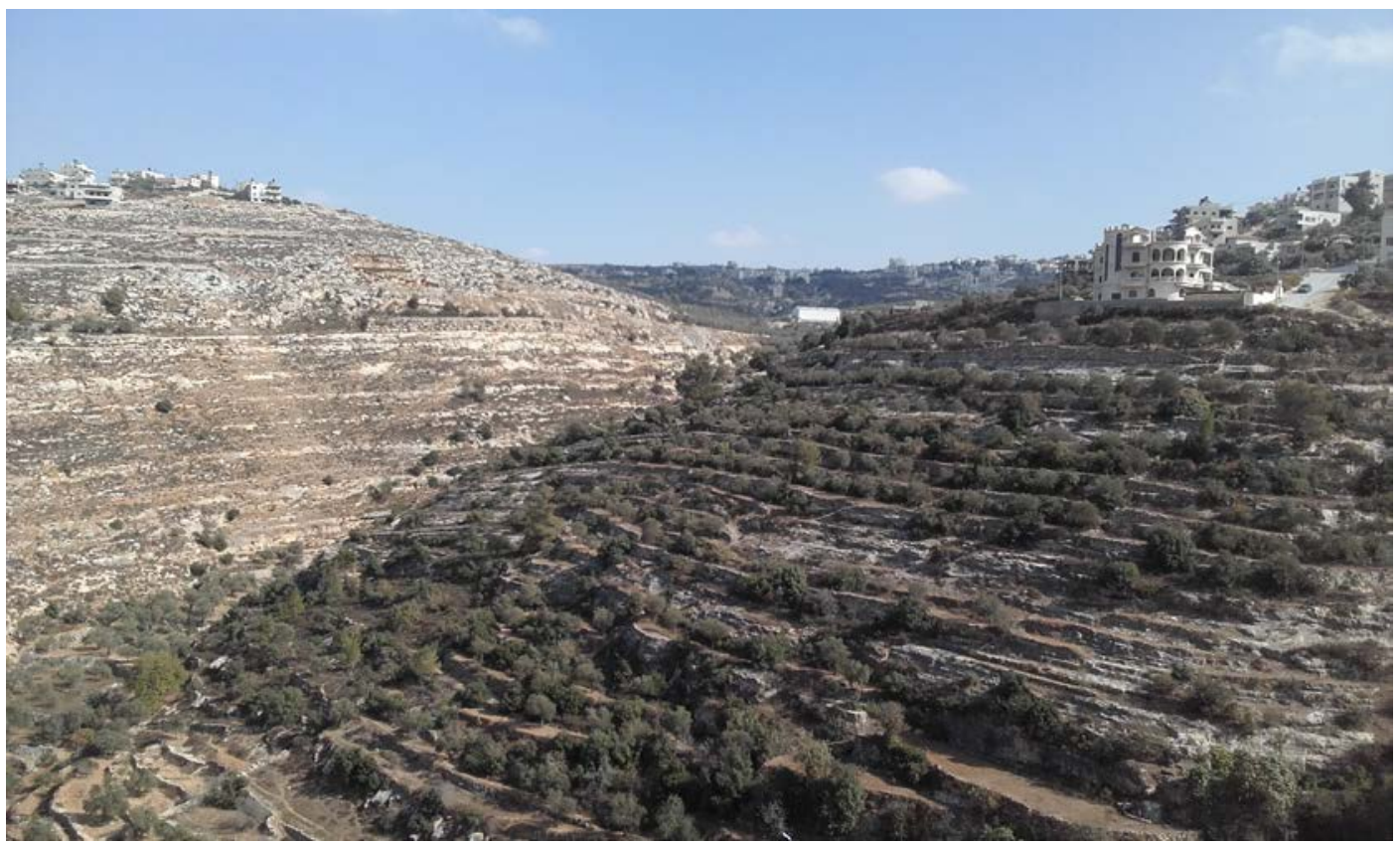

Figure 4: Traditional agricultural terraces in Battir village (next to Bethlehem), planted with olive trees. Source: authors. 


\section{Wastewater-driven pioneer fronts}

The PA and foreign donors drive wastewater pioneer fronts in the West Bank. They put forward a technical discourse portraying these changes as improvements in the efficiency of water management. While the development of wastewater pioneer fronts entails a profound political transformation of Palestinian society, this is made invisible in the discourse put forward by donors, consultants and the PA itself. Such mechanisms have been described elsewhere as an 'anti-politics machine' (Ferguson 1990).

The absence of wastewater treatment plants in the West Bank was a bone of contention for a long time between Israel and the PA. Israel has used the import duties it levies on goods imported into Palestinian territory to build and operate a series of wastewater treatment plants, inside Israel, along the Green Line, that capture water flowing from the West Bank (Fischhendler 2008). In 2017, Israel thus charged the PA US\$35 million for the treatment of wastewater entering it from the West Bank. The PA has now completed building wastewater treatment plants in al-Bireh (south of Ramallah), Ramallah, West Nablus, Jenin, Hebron and Jericho thanks to foreign donors. They produce treated wastewater varying in quality from A to C depending on the treatment plant. The treated wastewater they produce is considered a resource by several actors intent on using it in irrigation or for industrial uses. The Palestinian Law on agriculture number 2 of 2003 specifies in article 55 "The irrigation of agricultural crops with waste water shall be totally prohibited unless it has been treated in accordance with the national standards which are certified by the competent technical authorities." These standards are higher than Israeli standards and, in effect, forbid the use of treated wastewater in irrigating anything but fodder or fruit trees.

Several PA projects now propose to reuse this treated wastewater for irrigation. They systematically portray its release to the environment as a waste. This is coherent with the National Water and Wastewater Strategy for Palestine which aimed, in 2013, to supply $4.2 \mathrm{Mm}^{3} /$ year of treated wastewater to irrigation by 2017 (National Water and Wastewater Strategy for Palestine 2013). The same strategy document planned a meteoric rise of the reuse of wastewater in irrigation over the following years: $31.7 \mathrm{Mm}^{3} /$ year by $2022,58.5$ $\mathrm{Mm}^{3} /$ year in 2027, and $93.0 \mathrm{Mm}^{3} /$ year in 2032. It planned, on the long term, to leave only 40 percent of the treated wastewater to recharge the aquifer and expected a drop in groundwater used in irrigation from 51.0 $\mathrm{Mm}^{3}$ /year in 2012, to $45.8 \mathrm{Mm}^{3} /$ year in 2017, $40.5 \mathrm{Mm}^{3} /$ year in 2022, $35.3 \mathrm{Mm}^{3} /$ year in 2027 and 30.0 $\mathrm{Mm}^{3}$ /year in 2032 .

At the time the PA adopted this strategy, in 2013, all groundwater irrigated Palestinian agriculture depended on springs and on licensed or unlicensed wells that were never managed by the Palestinian Water Authority. The springs and most licensed wells were managed as common property regimes by formal or informal farmer institutions. A minority of the licensed wells and all of the unlicensed wells were managed as private property. How did the PA expect to implement this planned reduction in groundwater irrigation? This remains unexplained within its strategy document, the National Water and Wastewater Strategy for Palestine (2013). Perhaps it expected urbanization combined with the impact of the Israeli separation wall to eliminate groundwater irrigation. Perhaps it expected springs drying up to eliminate surface irrigation. Yet, it didn't warn farmers investing in pioneer fronts linked to licensed wells that their projects were doomed.

A common assumption is that the reuse of wastewater replaces groundwater and spring water in irrigation. A policy document adopted by the Palestinian Water Authority but written by French consultants states "While the treatment of used water protects the quality of water resources (whether they come from sources on the surface, springs or aquifers), reuse provides an additional water resource, replacing water extracted in particular for agriculture, which consumes more water than any other activity." (Study of the state and the economical importance of the reuse of treated wastewater in the West Bank (Palestine) 2017: 6). This assumption implies that irrigating farmers relying on groundwater or springs would be first in line to receive treated wastewater. Yet, examining the present wastewater reuse projects shows this is not the case. They overwhelmingly aim to bring the resource to newcomers in irrigation.

A project proposal aims to construct a trunk line bringing treated wastewater from al-Bireh, located next to Ramallah at 698 meters above sea level, to al-Auja, located in the Jordan Valley 250 meters below sea level, and to Deir Dibwan, a village located midway along the projected trunk line. It is still looking for a donor after the EU paid $€ 425,400$ (US\$493,323) for its feasibility study delivered in August 2016. Another 
project proposes to reuse the treated wastewater produced by West Nablus wastewater treatment plant over three different expanses of land located next to the plant. USAID funds the 12 hectare irrigation scheme south of the plant and KfW, German aid, funds the 280 hectare one planned northeast of the plant, as well as the 12 hectare scheme next to the plant.

A closer look at these projects shows they are not bringing water to irrigating farmers desperate to receive it, because their water supply is compromised. Irrigation from the West Nablus wastewater treatment plant targets land mostly covered with rain-fed olive trees. Most of the numerous small plots of land making up the two expanses of land belong to people whose main activity is not farming and have no experience with irrigation. The other project shows similarities. Deir Dibwan village long resisted proposals to use the treated wastewater produced by al-Bireh plant. In a typical study arguing that treated wastewater provides 'additional' supplies, Abu-Madi, Mimi, and Sinokrot considered in 2009 that "Reuse schemes may face public opposition resulting from a combination of prejudiced beliefs, fear, attitudes, lack of knowledge and general distrust, which is often not unjustified, judging by the frequent (and highly publicized) failures of wastewater treatment facilities worldwide." (Abu-Madi, Mimi, and Sinokrot 2009). The authors concluded that Deir Dibwan was reluctant to use wastewater generated by other communities. Maybe the upheaval in land and water tenure entailed by the reuse project better explains the reluctance of Deir Dibwan villagers.

Feasibility studies for such water reuse projects systematically reiterate the idea that treated water is wasted when it is released in the environment. They portray it as 'additional supplies of water' (Environmental and Social Impact Assessment for Al-Bireh Reuse Trunk Line to Al-Auja Area 2016). When they refer to the legal framework, they mention PA laws, Israeli military orders, Jordanian laws that still apply and, even, in some cases, European environmental regulations. They systematically ignore the forms of water tenure that presently exist within the localities targeted by the projects. Thus, they make the grassroots laws elaborated by these peasant irrigating communities invisible. They portray irrigation in terms of surface area, volumes of water and crop yields. They do not consider the social capital constructed within irrigating communities through their forms of water tenure.

Common property regimes governing water are complex. They deploy locally elaborated categories that rarely match those used by formal state laws. And they keep evolving over time as a reaction to climate, economic and social change (Boelens 2009). The feasibility study for the al-Bireh al-Auja trunk line (2016) mentioned that no Water User Association (WUA) existed in al-Auja. Yet, the community has devised and implemented a common property regime to manage its spring since the nineteenth century. Clearly a long established WUA exists here even though it doesn't have written statutes. But it is considered inexistent because it was not created by a license granted by the PA according to law No 3/2002 and decree 2/06/2014.

Al-Auja spring largely disappeared since 2009 probably because of interference from a new well. ${ }^{3}$ The water right holders within the spring common property regime consider they should have priority in receiving the treated wastewater. Under the common property regime, no one paid for water. The reluctance towards treated wastewater stems in part from the fact that it will eventually be supplied at a cost. It also stems from the fact that the present water users receive widely differing shares within the present common property regime. Such systems rarely distribute water equally to every shareholder. Allowing the arrival of treated wastewater means transforming the present distribution of the resource and its usufruct to a wholly different basis. Those who had enough capital to speculate on land when the spring dried up, and to undertake the massive plantation of date palms, will no doubt benefit far more than the others. The Environmental and Social Impact Assessment (ESIA) even mentioned in its executive summary that the project was expected to irrigate date palm trees (Environmental and Social Impact Assessment for Al-Bireh Reuse Trunk Line to AlAuja Area 2016). Up to 2011, bananas irrigated from the spring had predominated, all sold on the local market. The trees died for lack of water. Land was sold cheaply and date palms started appearing at the same time the reuse project was formulated.

\footnotetext{
${ }^{3}$ Rimmer (2011) demonstrated this could be due either to a well drilled for the PWA thanks to German aid, in the Ein Samia well field, to supply Ramallah with drinking water or to wells operated by the Israeli water company Mekorot, in Auja Na'aran well field.
} 


\section{The global ramifications of local pioneer fronts}

We identified three types of pioneer fronts in the West Bank: the first, driven by licensed wells, the second, driven by unlicensed wells and the third driven by wastewater reuse. All redirect water from a previous trajectory to a new trajectory. In each case, the previous trajectory placed water management in the hands of certain institutions, whether they be formal or informal. One type of pioneer front alone leaves decision-making concerning water management in the hands of the institutions that elaborated its tenure. Groundwater pioneer fronts relying on licensed wells do not alter water tenure. However, the two other types of pioneer fronts place the resource in the hands of new institutions and very different modes of tenure.

These changes in tenure are drastic. Pioneer fronts relying on unlicensed wells remove water from common property regimes that managed the springs they dry off to place it in the hands of private well owners. The change from common property regime to private property regime often means that an 'outsider' appropriates the resource. Indeed, a common property regime necessarily emerges from the interactions among a community. So members of the community would face steep social pressure if they dug a well that deprived the extended family and neighbors from their shared resource. Such a role is more easily played by an outsider. That outsider is Palestinian but they usually never belong to the community of shareholders owning the spring they dry off. Such an outsider may be a city dweller with a full-time job outside of agriculture. The subsequent licensing of these wells completes the dispossession of the spring users as the PA officially recognizes this private well.

Pioneer fronts relying on wastewater reuse claim to bring 'additional' water to areas that were not previously irrigated. This claim is questionable. When treated wastewater is released into the environment, it enters the aquifer and later reappears in the hands of those who devised modes of tenure to manage wells and springs. The planned trunk line between al-Bireh and al-Auja would allow water to short-circuit its previous trajectory through the wadi, seeping into the ground, replenishing springs and wells on the way while also feeding the environment. Once in the Jordan Valley, this water will be used once only before being consumed by evaporation or evapotranspiration or reaching the Dead Sea. If this water had followed a natural course, it could have been used many times, and by many institutions, before being consumed. Instead, wastewater reuse projects place water in the hands of the Palestinian Authority's institutions alone. The impacts on tenure are summarized in Table 1.

\begin{tabular}{|cll|}
$\begin{array}{l}\text { Source of water for the pioneer } \\
\text { front }\end{array}$ & $\begin{array}{l}\text { Change in tenure } \\
\text { Licensed wells }\end{array}$ & $\begin{array}{l}\text { Networks driving the pioneer } \\
\text { front }\end{array}$ \\
\hline Unlicensed wells & $\begin{array}{l}\text { From common property regime to } \\
\text { private property regime }\end{array}$ & $\begin{array}{l}\text { Local farmers and donors } \\
\text { Authority }\end{array}$ \\
\hline Treated wastewater & $\begin{array}{l}\text { From common property regime to } \\
\text { public property regime }\end{array}$ & Palestinian Authority and donors \\
\hline
\end{tabular}

Table 1: Pioneer fronts and water tenure transformation.

In each of these interstitial pioneer fronts, global actors and interactions appear. This occurs directly, through the interventions of donors, and indirectly, through the production of a globalized discourse about efficiency in irrigation. The same donors fund both the reservoirs required by the small irrigating farmers, who cultivate high in the mountain and rely on distant licensed wells, and the wastewater treatment plants and accompanying irrigation reuse schemes. The same donors also fund the feasibility studies of infrastructure such as the trunk line between al-Bireh and al-Auja. Direct donor intervention does not overtly seek water tenure change. Actually, the Agence Française de Développement, the French donor, has an official policy of supporting common property resource management. Yet, the wastewater treatment projects it funds in 
Palestinian Territories contribute to the elimination of this type of tenure. Understanding such a paradox requires an exploration of the scientific discourse that is produced by globalized actors involved in water management.

Global fora, such as the Global Water Partnership, the World Water Forum or the Swedish International Water Institute, have sanctioned the present dominant scientific discourse concerning water management. This process included an interaction between the scientific method and social, political and economic considerations. In other words, this process embedded a construction of the "natural order" and the "social order" (Jasanoff 2004). The globally constructed discourse on 'efficient' or 'sustainable' water management guides donors when designing projects and selecting 'successful' farmers worthy of receiving the resource (Trottier and Perrier 2017). Such a globalized discourse has shaped the Palestinian Ministry of Agriculture's definition of irrigable land as based on soil quality, slope and accessibility. This definition is designed for export-oriented agribusinesses. It excludes consideration of existing farmers' experience in irrigation, especially in mountain irrigation over small plots and combined with rain-fed farming.

The globalized scientific discourse on sound water management has long shaped the Palestinian national water strategy. For instance, international consultants drafted the 2002 Palestinian water law on the basis of principles promoted in international fora, neglecting to incorporate the legal categories developed by long established, informal, local water management institutions. As a result, the 2002 law was not implemented and local water management practices persisted (Trottier 2007). The 2002 water law was promulgated in English and was translated into Arabic several years later. Even the website of the Palestinian Authority only existed in English for several years (Brooks and Trottier 2010). The Palestinian National Water Strategy is an official document that states an aim to direct most water reuse to the Jordan Valley, where agribusinesses relying on contract farming are already located (National Water and Wastewater Strategy for Palestine 2013). Such an aim reflects the globalized scientific discourse on sound water management.

Donor -funded project documents insist on the importance of WUAs. Yet, the projects never recognize existing irrigating farmers' organizations and never reach out to them. The WUA foreseen by the projects are expected to abide by the new mode of tenure that is linked with them. Tenure is defined as the relationship, either legally or customarily defined, between people, as individuals or groups, with respect to a resource (Hodgson 2016). In other words, tenure is a social construction. It can be formal or informal. It can be individual or collective. Customary forms of tenure, although collective, never distribute water equally among all shareholders. But they distribute it in a manner that is considered equitable within the community. The WUAs foreseen by donor-funded projects exclude those that embody customary and/or informal forms of tenure. Donor funded projects only cater to WUAs that match the precepts of the globally constructed discourse on sound water management. These WUAs don't exist in Palestinian Territories. This is especially problematic when they are created to match donors' expectations. Their paperwork is then spotless but their members sometimes don't include farmers cultivating land in the project scheme.

Land tenure is enmeshed in water tenure in many ways that systematically embed mechanisms protecting food security and various other forms of security for the local resource users. For example, in the West Bank, landowners systematically grant permission to pick khubbezeh, a nutritious variety of mallow, on their fields. Villagers rationalize this right by saying that khubbezeh is a weed and does not result from the farmer's work. But, in the Jordan Valley, its growth relies on the leaks from farmers' irrigation system. The right of poor people to pick khubbezeh contributes to their food security. Similarly, in the Jordan Valley, sharecroppers usually live on the land they cultivate. They may build a shack out of pallets and plastic sheets and connect this 'temporary' home to the electricity grid and to the irrigation water network. Sharecroppers who live in such inhabitations say that they are camping there but live elsewhere. Such camping lasts ten months every year. And many sharecroppers farm the same plots for decades together with their wife and children. Land and water tenure are not only enmeshed in each other. They are also enmeshed in mechanisms that ensure food and housing security. Donor funded projects driving interstitial pioneer fronts do not take into account the forms of land tenure that interact with water tenure in peasant irrigation. 
Each type of pioneer front has a different impact on the social organization of agricultural production. Sharecropping is widespread in the eastern aquifer. It remains rare in the western aquifer. Reuse schemes entail changes in crops, often replacing sharecroppers with laborers. In West Nablus, the German donor picked the crops for its reuse scheme on the basis of evapotranspiration levels without considering whether these crops would require a new form of social organization for their production. The ESIA for the pipeline linking al-Bireh and al-Auja states in its executive summary that most of the reused water is expected to irrigate date palm trees. This entails a profound change for the local society. Bananas had been cultivated by sharecroppers. Date palm trees are cultivated by laborers. Sharecropping is family work. Sharecropping families often live on the land they cultivate and use it to grow their own food. In open land, sharecropping contracts are called nosnos, i.e. 'halfhalf' because the landowner receives 50 percent of the crop's revenue. In greenhouse agriculture, the landowner usually receives 75 percent of the revenue. Sharecroppers often have deep roots in the land they cultivate, sometimes for decades. Laborers can be brought in from far away places when the owner needs them. In Israel, and in Israeli agricultural settlements in the Jordan Valley, many agricultural workers are Thais who must return home once their five year work permit expires. This could be the future of Palestinian agriculture if the present interstitial pioneer fronts keep developing as they are today.

Our scientific discourse on the environment is unavoidably linked with the manner in which we want to manage it (Jasanoff 2004). We never produce a neutral scientific discourse on the environment, on what constitutes 'efficient' or 'sustainable' resource use (Forsyth 2003). The present definition of these terms entails bringing water into market-based relations, commodifying it, and transforming its users into customers. We could define efficiency differently. Examining the trajectories of previously 'wasted' water reveals who was using it according to which form of tenure. Common property regimes often manage water sustainably (Ostrom et al. 2002). Their privileging of equity among users contributes to food security and to a social capital that produces many useful externalities. Tracking the changing trajectories of water when local pioneer fronts develop allows us to trace the changes in water tenure and, subsequently, land tenure.

Exploring how the development of interstitial pioneer fronts impacts the trajectories of water demonstrates how efficiency in water use can mean very different things for different actors. When turning to treated wastewater means switching from crops cultivated by sharecroppers to crops cultivated by laborers, sharecropping families have to move and look for other land to cultivate. They lose the mechanisms that ensured their food security and their housing security. The massive uprooting of farmers in Syria during the drought of 2005 led Syria, years later, into a brutal civil war (de Châtel 2014). This could also be the future of the West Bank if the present interstitial pioneer fronts keep developing.

Understanding how existing interstitial pioneer fronts interact with the transformation of Palestinian society allows understanding local reactions. Farmers resist wastewater reuse persistently. At the West Nablus treatment plant, donors plan to provide the irrigation scheme and the water free of charge for two years to enroll farmers. Nevertheless, the land slotted for the irrigation scheme by USAID remains a patchwork of small plots because many owners refuse to participate. The East Nablus wastewater treatment, planned for 20 years, remains unconstructed because of the ferocious opposition from Salim, Azmout and Deir al-Hattab villagers. Der Dibwan has refused the reuse schemes irrigated with al-Bireh treated wastewater for over ten years. Al-Auja sharecroppers tried to voice their concerns at the ESIA meeting in 2014 (Environmental and Social Impact Assessment for Al-Bireh Reuse Trunk Line to Al-Auja Area 2016). The resulting report demonstrates they were not heard. Such resistance is systematically portrayed as 'acceptability problems' for 'cultural reasons' concerning an unclean resource. Our study shows this resistance stems from the farmers' understanding that these pioneer fronts threaten their modes of tenure and their livelihoods. Many rightly fear a situation of reverse tenancy where they lose control over their resources.

The Palestinian national water strategy claims that reusing treated wastewater in irrigation will relieve the pressure on groundwater. If this were true, then it would constitute an example of green grabbing. However, as the reuse projects aim to allocate the resource to farmers who were not relying on groundwater, it will not reduce groundwater consumption. Moreover, as the trunk line between al-Bireh and al-Auja will short-circuit the trajectory of treated wastewater through the aquifer, it will reduce aquifer recharge. The pioneer fronts we observe thus correspond more to green washing rather than to green grabbing. 


\section{Concluding remarks}

Kopytoff demonstrated interstitial frontiers, where new ethnic identities were forged, necessarily remained transient phenomena. Either the new ethnicity became dominant and expanded its territory, or it disappeared. Similarly, the interstitial agricultural frontiers we observe here (Figure 3) are necessarily transient phenomena. Either they will complete the dispossession and destruction of the surrounding modes of land and water tenure, or the social fabric of Palestinian society will successfully resist.

Groundwater driven pioneer fronts based on licensed wells are quite vulnerable to bankruptcy. The investments they require are not commensurate with the revenues they eventually generate. Groundwater driven pioneer fronts based on unlicensed wells are vulnerable to destruction by the Israeli authorities. Reports of "soldiers" pouring cement in such wells to destroy them are common. Such unlicensed wells' sustainability depends on their owner's proximity to the Palestinian Authority or Israel and their ability to secure a license after they have started operating the well. Wastewater driven pioneer fronts are vulnerable to the resistance that Palestinian farmers may or may not pose to the transformation this entails in their society. This resistance will probably be weakest in the Jordan Valley, where sharecropping has long been widespread and landowners have long lived in cities such as Jerusalem or Ramallah, far from their fields.

Such phenomena are not idiosyncratic to the Israeli Palestinian conflict. They result from interactions among investors, donors and state authorities. Barnes' work in Egypt (2012), Leblond's in Mozambique (2017) and Amichi et al.'s in Algeria (Amichi et al. 2015) illustrate similar mechanisms. These constitute a large part of the interface between globalization and grassroots forms of resource tenure. Everywhere, a respect for democracy, equitable development and environmental justice would require the donors and the national governments to take all of these actors and all of their predicaments into consideration.

\section{References}

Abu Madi, M., Z. Mimi and N. Sinokrot. 2009. Building a participatory national consensus on wastewater reclamation and reuse in Palestine. Second International Conference on the Palestinian Environment, An-Najah National University, Nablus.

Alfarra, A., E. Kemp-Benedict, H. Hötzl, N. Sader and B. Sonneveld. 2011. A framework for wastewater reuse in jordan: utilizing a modified wastewater reuse index. Water Resources Management 25(4): 1153-1167.

Allan, T., M. Keulertz, S. Sojamo and J. Warner. 2013. Handbook of land and water grabs in Africa: foreign direct investment and food and water security. London: Routledge.

Amichi, F., S. Bouarfa, C. Lejars, M. Kuper, T. Hartani, A. Daoudi, H. Amichi and M. Belhamra. 2015. Des serres et des hommes: des exploitations motrices de l'expansion territoriale et de l'ascension socioprofessionnelle sur un front pionnier de l'agriculture saharienne en Algérie. Cahiers Agricultures 24(1): 11-19.

Baker Brite, E. 2016. Irrigation in the Khorezm oasis, past and present: a political ecology perspective. Journal of Political Ecology 23:1-25.

Barnes, J. 2012. Pumping possibility: agricultural expansion through desert reclamation in Egypt. Social Studies of Science 42(4): 517-538.

Bassett, T.J. 1988. The political ecology of peasant herder conflicts. Annals of the Association of American Geographers 78(3): 453-472.

Beveridge, R., T. Moss and M. Naumann. 2017. Sociospatial understanding of water politics: tracing the multi-dimensionality of water reuse. Water Alternatives 10(1): 22-40.

Boelens, R. 2009. The politics of disciplining water rights. Development and Change 40(2): 307-331.

Boujnikh, M. and A. Humbert. 2010. L'eau dans le bassin du Souss: concurrences et désorganisation des systèmes paysans. Norois 214: 113-126.

Brooks, D. and J. Trottier. 2010. Confronting water in the Palestinian-Israeli conflict. Journal of Hydrology 382: 103-114. 
Chamberlin, J., T.S. Jayne and D. Headey. 2014. Scarcity amidst abundance? Reassessing the potential for cropland expansion in Africa. Food Policy 48: 51-65.

de Châtel, F. 2014. The role of drought and climate change in the Syrian uprising: untangling the triggers of the Revolution. Middle Eastern Studies 50(4): 521-535.

Chauveau, J.-P., J.-P. Jacob and P.-Y. Le Meur. 2004. L'organisation de la mobilité dans les sociétés rurales du Sud. Autrepart 30(2): 3-23.

Cochet, H., É. Léonard and B. Tallet. 2010. Le métayage d'élevage au Mexique. Colonisations foncières et dynamiques d'une institution agraire dans l'histoire contemporaine. Annales de Géographie 6(676): 617-638.

de Planhol, X. 1968. Les fondements géographiques de l'histoire de l'Islam. Paris: Flammarion.

De Schutter, O. 2011. How not to think of land-grabbing: three critiques of large-scale investments in farmland. Journal of Peasant Studies 38(2): 249-279.

Edelman, M. 2013. Messy hectares: questions about the epistemology of land grabbing data. Journal of Peasant Studies 40(3): 485-501.

Environmental and Social Impact Assessment for Al-Bireh Reuse Trunk Line to Al-Auja Area 2016. Palestinian Water Authority, Ramallah.

Fairhead, J., M. Leach and I. Scoones. 2012. Green grabbing: a new appropriation of nature? Journal of Peasant Studies 39(2): 237-261.

Ferguson, J. 1990. The anti-politics machine. Cambridge: Cambridge University Press.

Fischhendler, I., S. Dinar and D. Katz. 2011. The politics of unilateral environmentalism: cooperation and conflict over water management along the Israeli-Palestinian border. Global Environmental Politics 11(1): 36-61.

Forsyth, T.J. 2003. Critical political ecology. London: Routledge.

Goldman, M., P. Nadasdy and M.D. Turner (eds.). 2011. Knowing nature: conversations at the intersection of political ecology and science studies. Chicago: University of Chicago Press.

Gomiero, T. 2016. Soil degradation, land scarcity and food security: reviewing a complex challenge. Sustainability 8(281): 1-41.

Granott, A. 1952. The land system in Palestine. London: Eyre \& Spottiswoode.

Grecchi, R.C., Q.H.J. Gwyn, G.B. Bénié, A.R. Formaggio and F.C. Fahl. 2014. Land use and land cover changes in the Brazilian Cerrado: a multidisciplinary approach to assess the impacts of agricultural expansion. Applied Geography 55: 300-312.

Hertel, T., J. Steinbuks and U. Baldos. 2013. Competition for land in the global bioeconomy. Agricultural Economics 44: 129-138.

Hodgson, S. 2016. Exploring the concept of water tenure. Land and Water Discussion Paper 10. Rome: Food and Agriculture Organization of the United Nations.

Jasanoff, S. 2004. States of knowledge. London: Routledge.

Jepson, W. 2006. Producing a modern agricultural frontier: firms and cooperatives in Eastern Mato Grosso, Brazil. Economic Geography 82(3): 289-316.

Kopytoff, I. 1987. The internal African frontier: the making of African political culture. In I. Kopytoff. (ed.) The African frontier: the reproduction of traditional African societies. Bloomington: Indiana University Press, Pp. 3-86.

Krishna Bahadur, K.C. 2012. Spatio-temporal patterns of agricultural expansion and its effect on watershed degradation: a case from the mountains of Nepal. Environmental Earth Sciences 65(7): 2063-2077.

Lankford, B. 2013. Resource efficiency complexity and the commons: the paracommons and paradoxes of natural resource losses, wastes, and wastages. London: Routledge.

Leblond, N. 2017. Gouverner l'agriculture grâce aux modèles? Le cas du CAADP au Mozambique. CyberGéo: European Journal of Geography Document 815. 
Léonard, É. 2004. La réforme agraire mexicaine comme processus de frontière. Logiques d'autonomisation, ancrage de l'État et production institutionnelle dans la région des Tuxtlas. Autrepart 30(2): 97-116.

Lichtenthaler, G. 2003. Political ecology and the role of water, environment, society and economy in Northern Yemen. Aldershot: Ashgate.

Mehta, L., G.J. Veldwisch and J. Franco. 2012. Introduction to the Special Issue: water grabbing? Focus on the (re) appropriation of finite water resources. Water Alternatives 5(2):193-207.

Wade Miller, G. 2006. Integrated concepts in water reuse: managing global water needs. Desalination 187(13): 65-75.

National Water and Wastewater Strategy for Palestine. 2013. Palestinian Water Authority.

OCHA. 2015. Humanitarian Atlas. United Nations Office for the Coordination of Humanitarian Affairs occupied Palestinian territory.

Ostrom, E., T. Dietz, N. Dolsak and P. Stern. 2002. The drama of the commons. Washington: National Academy Press.

Oya, C. 2013. Methodological reflections on 'land grab' databases and the 'land grab' literature 'rush'. Journal of Peasant Studies 40(3): 503-520.

Peluso, N.L. and C. Lund. 2011. New frontiers of land control: introduction. Journal of Peasant Studies 38(4): 667-681.

Pfister, S., P. Bayer, A. Koehler and S. Hellweg. 2011. Projected water consumption in future global agriculture: scenarios and related impacts. Science of the Total Environment 409(20): 4206-4216.

Ribot, J.C., Peluso, N.L. 2003. A theory of access. Rural Sociology 68: 153-181.

Rimmer, A. 2011. Hydrological survey of Auja Spring. Tel Aviv: Friends of the Middle East.

Sitko, N.J. and T.S. Jayne. 2014. Structural transformation or elite land capture? The growth of 'emergent' farmers in Zambia. Food Policy 48: 194-202.

Smaller, C. and H. Mann. 2009. A thirst for distant lands: foreign investment in agricultural land and water. Winnipeg: International Institute for Sustainable Development.

Study of the state and the economical importance of the reuse of treated wastewater in the West Bank (Palestine). 2017. Adour Garonne and Palestinian Water Authority.

Trottier, J. 1999. Hydropolitics in the West Bank and Gaza Strip. Jerusalem: PASSIA.

Trottier, J. 2007. A wall, water and power: the Israeli "separation fence". Review of International Studies 33(1): 105-127.

Trottier, J. 2013. The social construction of water management at the intersection of international conflict: the case of Al Auja. Eurorient 44: 161-181.

Trottier, J. 2015. Le rapport à l'eau et à la terre dans la construction de territoires multisitués: le cas palestinien. L'Espace géographique 44(2): 103-114.

Trottier, J. and J. Perrier. 2017. Challenging the coproduction of virtual water and Palestinian agriculture. Geoforum 87: 85-94.

Tomazi, A.H. and S. Naslun. 2005. Water rights. In Abdulfattah and B. de Vries (eds.). Wadi el-Far'a project report: an environmental assessment of the Wadi el-Far'a watershed. Ramallah: Birzeit University. Pp. 118-140.

White, B., S.M. Borras Jr., R. Hall, I. Scoones and W. Wolford. 2012. The new enclosures: critical perspectives on corporate land deals. The Journal of Peasant Studies 39(3-4): 619-647.

Woodhouse, P. 2012. New investment, old challenges. Land deals and the water constraint in African agriculture. The Journal of Peasant Studies 39(3-4): 777-794.

Woodhouse, P., G.J. Veldwisch, J.-P. Venot, D. Brockington, H. Komakech and Â. Manjichi. 2017. African farmer-led irrigation development: re-framing agricultural policy and investment? The Journal of Peasant Studies 44(1): 213-233. 
Zoomers, A. 2010. Globalisation and the foreignisation of space: seven processes driving the current global land grab. The Journal of Peasant Studies 37(2): 429-447. 